\title{
FERNANDO DE AZEVEDO (1894-1974): UMA MESMA OBRA E SUAS VÁRIAS LEITURAS
}

\author{
Silvia Helena Andrade de Brito ${ }^{1}$ \\ Maria Angélica Cardoso ${ }^{2}$
}

\begin{abstract}
RESUMO
Intelectual reconhecido por sua verve poderosa, que discutiu os temas mais relevantes da questão educacional e das ciências sociais no Brasil entre os anos 1920 e 1960, Fernando de Azevedo (1894-1974) certamente permite variadas leituras acerca de sua produção. O objeto deste artigo são essas leituras, oriundas de autores dos campos educacional e sociológico, produzidas entre 1979 e 2011. Os objetivos desse artigo são analisar essas leituras sobre Azevedo, por um lado; e, por outro, fundamentar a necessidade de uma releitura de suas obras, tendo por norte as categorias "trabalho didático" e "organização do trabalho didático". Para justificar essa proposição, afirme-se que grande parte dos textos compulsados volta-se ao estudo das propostas políticas de Fernando de Azevedo, destacando seu papel como reformador e artífice de uma nova educação, para um novo Brasil. Outro tema emergente é a figura do cientista social, voltado à consolidação da sociologia no país. Em função disso, justifica-se a necessidade de examinar-se uma outra faceta de sua obra, presente nos seus compêndios, nos projetos de reforma educacional, nas propostas para a formação tanto dos profissionais da sociologia como da educação, que uma leitura focada na questão do trabalho didático permitirá trazer ao primeiro plano.

Palavras-chave: Fernando de Azevedo; trabalho didático; Escola Nova
\end{abstract}

\section{FERNANDO DE AZEVEDO (1894-1974): THE SAME TEXT AND ITS VARIOUS READINGS}

\begin{abstract}
Intellectual recognized for his powerful verve, who discussed the most important themes of educational issue and the social sciences in Brazil between 1920 and 1960, Fernando de Azevedo (1894-1974) certainly allows multiple readings about his production. These readings, arising from authors of educational and sociological fields, produced between 1979 and 2011, are the subject of this article. Its objectives are, on the one hand, to analyze these readings on Azevedo, and, on the other hand, ground the need for a re-reading of his works, having as north "didactic work" and "organization of didactic work" categories. In order to support this proposition, it is asserted that most of the analyzed texts back to the study of policy proposals from Fernando de Azevedo, highlighting his role as a reformer and proponent of a new education for a new Brazil. Another emerging theme is his figure as the social scientist, focused on the consolidation of sociology in the country. Therefore, it is justified the need to look over another facet of his work, this in his textbooks, in his educational reform projects, in his proposals for the formation of both the sociology and education professional that a reading focused on question of the didactic work will allow to bring to the foreground.
\end{abstract}

Keywords: Fernando de Azevedo; didactic work; New School. 


\section{Introdução}

Autor de uma vasta produção que inclui cerca de 25 volumes, entre textos sociológicos (Um trem corre para o Oeste, de 1950; A cidade e o campo na civilização industrial, de 1962); ensaios sobre temas variados, principalmente sobre a questão educacional (Novos caminhos e novos fins, de 1958; A educação na encruzilhada, de 1960); trabalhos sobre homens públicos e educadores, incluindo-se aqui textos autobiográficos (Máscaras e retratos, de 1962; Figuras de meu convívio, de 1960; História de minha vida, de 1971) e compêndios didáticos voltados para os ensinos de sociologia, sociologia educacional e latim (Princípios de Sociologia, de 1935; Sociologia Educacional, de 1940; Páginas Latinas, de [19??]), Fernando de Azevedo (1894-1974), com certeza, se situa entre os mais profícuos pensadores a se debruçar sobre os dilemas e possibilidades que envolveram a sociedade no Brasil, sobretudo na primeira metade do século XX.

Ora, uma obra com tal envergadura gerou e gera inúmeras indagações, apresentadas tanto por educadores, como por sociólogos que se dedicaram à reflexão de sua produção. Nesse sentido, o objeto da presente comunicação são as interpretações produzidas acerca de Fernando de Azevedo e seus textos, privilegiando aquelas referidas às áreas da educação e da sociologia. O objetivo do artigo é analisar, por um lado, o foco dessa produção, desvelando o que foi dito, por tais pesquisadores, acerca dos posicionamentos de Fernando de Azevedo. Por outro, visa-se apresentar uma outra proposta de leitura sobre o referido autor, dessa feita à luz das categorias trabalho didático e organização do trabalho didático, que foi o foco das preocupações em especial de Gilberto Luiz Alves (2001; 2005; 2010; 2012) .

Para realizar a referida discussão, o artigo está organizado em três partes. A primeira, na qual são apresentadas as discussões de autores do campo educacional e sociológico, que se debruçaram sobre a obra de Fernando de Azevedo. Em seguida, apresenta-se a proposta de análise a ser empreendida a partir da utilização das categorias trabalho didático e organização do trabalho didático, encerrando-se o texto com algumas considerações sobre os desafios que essa proposta de análise deverá enfrentar, para que seja efetivada.

\section{As visões de educadores e cientistas sociais sobre Fernando de Azevedo}

Alessandra Santos Nascimento (2011), em sua tese de doutorado, que teve como objeto o papel de Fernando de Azevedo no processo de institucionalização da sociologia no Brasil, aponta 15 trabalhos completos (teses, dissertações, relatórios de pesquisa e inventários analíticos) e 28 artigos (capítulos de livro e textos em periódicos) que tratam sobre esse educador escolanovista. A maior parte dos trabalhos citados por Nascimento foi produzida no campo educacional (quase $90,0 \%$ das teses, dissertações e relatórios de pesquisa e cerca de 40,0\% dos capítulos de livro e textos em periódicos), enquanto uma parte menos significativos dos textos têm pesquisadores oriundos da área das ciências sociais como seus autores. Nesse sentido, a autora lembra que entre os pesquisadores que tiveram como objeto a reconstituição do desenvolvimento das pesquisas sociológicas no Brasil, ou seja, 
[...] [na] história da Sociologia acadêmica no país, [...] [observa-se] uma relativa ausência de Azevedo, seja como um dos pioneiros desta ciência seja enquanto um dos protagonistas de sua institucionalização. (NASCIMENTO, 2011, p. 36).

Ao contrário, Fernando de Azevedo aparece como referência obrigatória quando se trata de discutir, na pesquisa educacional, o ideário que marcou o momento histórico que se estendeu entre os anos 1930 e 1960: ali, por um lado, se consolidou o movimento renovador no país, no embate com outros projetos educacionais, tal como a perspectiva cristã, entre os anos 1930 e 1940; e, por outro, as propostas da Escola Nova se tornaram hegemônicas no campo educacional, entre as décadas de 1950 e 1960 (SAVIANI, 2007).

Uma terceira posição, que se encontra na confluência dos campos educacional e sociológico é referida por autores como Flávio Marcos Silva Sarandy (2004) e Kátia Karine Duarte da Silva (2010), ao lembrarem que o retorno da disciplina sociologia ao ensino de $2^{\circ}$ grau, ainda nos anos 1980, e posteriormente ao ensino médio, nos anos 1990, motivou o adensamento da produção sobre o ensino de sociologia, inclusive entre cientistas sociais. Segundo Silva (2010), constata-se, por um lado, que a maior parte deste terceiro grupo de trabalhos priorizou o ensino de sociologia a partir dos anos 1990, sem necessariamente fazer menção à história do ensino de sociologia no Brasil, onde se poderia encontrar referência ao trabalho de Fernando de Azevedo.

Além disso, entre os trabalhos citados pela autora como aqueles que são marcados pela abordagem histórica, está o de Clóvis Pacheco Filho, em sua dissertação de mestrado defendida em 1994, junto ao Programa de Pós-Graduação em Educação da USP, intitulada Diálogos de surdos: As dificuldades para a construção da Sociologia e de seu ensino no Brasil (1850-1935), que tinha como objetivo fundamental analisar "[...] as contradições que envolveram a construção da Sociologia como pensamento científico e seu ensino no país, a partir de uma análise dos primeiros pensadores dos meados do século XIX e início do século XX" (SILVA, 2010, p. 7). Ou seja, Pacheco Filho (1994) privilegia o período histórico anterior àquele marcado pela hegemonia do escolanovismo. Já a dissertação de mestrado de Adriano Carneiro Giglio, A Sociologia na Escola Secundária: Uma Questão das Ciências Sociais no Brasil - Anos 40 e 50, apresentada ao Programa de Pós-Graduação em Sociologia do Instituto Universitário de Pesquisas do Rio de Janeiro (IUPERJ) em 1999, tinha como objeto o debate em torno de o ensino de sociologia na escola secundária no período histórico mencionado. Para tal, parte especialmente das reflexões de dois sociólogos considerados pelo autor como importantes interlocutores nesse contexto, a saber, Antônio Carneiro Leão e Florestan Fernandes.

Jefferson da Costa Soares é o autor da dissertação $O$ Ensino de Sociologia no Colégio Pedro II (1925 - 1941)", defendida junto ao Programa de Pós-Graduação em Educação da Universidade Federal do Rio de Janeiro, em 2009, cujo “[...] objetivo é desenvolver uma análise sócio-histórica da Sociologia no período de 1925 a 1941, no Colégio Pedro II, por esta ser a primeira instituição de ensino secundário no Brasil a introduzir a disciplina em seu currículo" (SILVA, 2010, p. 9). Para tal, trouxe para o debate os textos escolares de Carlos Miguel Delgado de Carvalho, o primeiro catedrático da disciplina naquela instituição de ensino. O último trabalho citado por Silva (2010) é o de Luciane Perucchi - Saberes sociológicos nas escolas de nível médio sob a ditadura militar: os livros didáticos de OSPB, defendido em 2009 no Programa de Pós-Graduação em Educação, na Universidade Federal de Santa Catarina (UFSC). Seu objeto é a presença da disciplina de sociologia no ensino médio durante o período ditatorial (1964-1984), 
quando os saberes sociológicos eram "[...] apresentados no conjunto de conhecimentos da disciplina Organização Social e Política Brasileira (OSPB)" (SILVA, 2010, p. 10).

O quinto e último trabalho citado por Silva (2010) é a dissertação de Simone Meucci, intitulada A institucionalização da sociologia no Brasil: os primeiros manuais e cursos, que está voltada para os textos escolares de sociologia e a inserção da disciplina nos ensinos secundário, normal e superior nos anos 1930 e 1940. Dessa forma, entre os cinco trabalhos históricos encontrados pela autora, apenas o de Meucci será parte dos trabalhos visitados nesse artigo, por tratar de questões que estão diretamente relacionadas ao autor aqui destacado, Fernando de Azevedo ${ }^{5}$.

Destaque-se ainda que, na impossibilidade de tratar, nos limites de um artigo, toda a bibliografia produzida sobre Azevedo, serão apresentadas algumas das referências mais citadas nos textos, sejam elas oriundos da área educacional ou da área sociológica.

No campo educacional, o primeiro trabalho a ser comentado é o de Nelson Piletti, filósofo, jornalista e pedagogo, cuja dissertação de mestrado, defendida em 1979 no Curso de Mestrado em Educação da Universidade de São Paulo (USP), versou sobre a reforma educacional promovida por Fernando de Azevedo no Distrito Federal, entre 1927 e $1930^{6}$.

Conforme Piletti (1994a, p. 182-183), Fernando de Azevedo foi um homem de forte presença, com múltiplos interesses intelectuais. Assim,

Da educação física [...] às ciências sociais, trajetória que completou em 20 anos, transitou pelo ensino de latim e de psicologia, pela crítica literária, pela investigação sobre a arquitetura colonial e sobre a educação paulista, pela reforma educacional. Estudioso e amante dos clássicos, nunca escondeu o seu fascínio pelas ciências modernas, que procurou incluir nos currículos escolares, tanto que, nos anos 50, organizou a obra As ciências no Brasil, [...]. Entre 25 livros, a maioria na área da educação, escreveu obras pioneiras no campo das ciências sociais como Princípios de Sociologia (1935), Sociologia, Educacional (1940) e Canaviais e engenhos na vida política do Brasil (1948).

Piletti destaca, partindo de uma carta de Paschoal Lemme (apud PILETTI, 1994, p. 182-183), o que considera as quatro contribuições fundamentais de Azevedo, no campo da educação e cultura no Brasil:

1. A grande reforma do ensino no antigo Distrito Federal (1927-1930) (...), reforma essa que, segundo as opiniões mais autorizadas, foi o marco inicial do processo de modernização do ensino no Brasil. 2. O Manifesto dos Pioneiros da Educação Nova (1932) (...), documento único na história da educação brasileira. (...) Subscrito por um grupo dos mais eminentes educadores e intelectuais, mantém até hoje sua validade. 3. A monumental obra A cultura brasileira, redigida inicialmente para servir de introdução ao recenseamento de 1940, tornou-se de consulta obrigatória para quem deseja conhecer a evolução da cultura nacional, em todos os seus aspectos (Carta ao Jornal do Brasil, 1976). A estas três poderíamos acrescentar uma quarta contribuição, que foi a sua importante participação no processo de fundação da Universidade de São Paulo (1934).

Além disso, em seus artigos, Piletti apresenta uma visão geral da vida e obra de Azevedo, especialmente questões sobre o Inquérito de 1926, a reforma educacional 
empreendida no Distrito Federal, o Manifesto de 1932, a fundação da USP e a defesa da escola pública. Enfatiza ainda a transição do especialista em educação física, em crítica literária e em educação dos anos 1920/1930, para o Fernando de Azevedo cientista social dos anos 1940 a 1960, quando se transformou radicalmente "[...] a concepção de Fernando de Azevedo acerca das relações entre a educação escolar e a sociedade [...], superando, segundo as suas próprias palavras, a 'concepção romântica do papel da Escola' (PILETTI, 1999, p. 183-184). Assim, são as inúmeras facetas de Fernando de Azevedo, enquanto intelectual, educador, homem público, sociólogo, entre outras, e como se expressou, em cada uma delas e em momento histórico de sua trajetória intelectual a questão da reforma educacional e do papel da educação, os temas que ocuparam as reflexões de Nelson Piletti.

Outras obras que aparecem na bibliografia sobre Azevedo são os textos de Maria Luiza Penna, cuja obra sobre Fernando de Azevedo foi produzida a partir de sua dissertação, defendida junto ao Curso de Mestrado em Filosofia da Pontifícia Universidade Católica do Rio de Janeiro (PUC-Rio), com o título Educação e Transformação em Fernando de Azevedo, no ano de $1981^{7}$.

Maria Luiza Penna inicia seus estudos afirmando que Azevedo, embora seja objeto de muitas críticas, ocupa lugar de destaque na história da educação brasileira - posição que, segundo a autora, é consensual entre vários estudiosos da educação no país. Para Penna (2010, p. 11), contudo, Azevedo "[...] esteve adiante da maioria dos educadores do seu tempo, levantando as bandeiras históricas da burguesia progressista e liberal”.

Paradoxal, o pensamento azevediano reflete as dificuldades de um mundo em transformação, que orbitou entre a Revolução de 1930 e a luta pelo Estado Democrático, por um lado; e que por outro, conheceu o Estado Novo, a Segunda Guerra Mundial, o fascismo e o totalitarismo.

Para a autora, Fernando de Azevedo pensou o "[...] Brasil com os instrumentos e categorias que lhe pareceram mais adequadas e com os quais realizou uma tomada de consciência da realidade educacional brasileira, suas especificidades, tendências, conflitos e necessidades" (PENNA, 2010, p. 13). Nesse sentido, sua produção intelectual está situada entre duas épocas - a das velhas tradições e a que se iniciou com a entrada do Brasil em um novo processo de modernização, após a Segunda Guerra Mundial - ou seja, entre 1926 e meados da década de 1960.

Assim, ligado a um grupo do jornal $O$ Estado de São Paulo, cujo núcleo era formado por intelectuais liberais, Fernando de Azevedo foi convidado a realizar um inquérito sobre a educação no Brasil, em 1926. Para Penna (2010, p. 15), foi esse inquérito que o lançou como o grande perito em educação, levando-o a enveredar pelos caminhos da sociologia e dos problemas da educação. Lembra a autora (PENNA, p. 16-17) que, para Azevedo, o inquérito tem o significado de uma "[...] volta ao real [o que] significa, [...] constatar a necessidade de uma luta reformista na esfera da educação, de uma radical mudança de mentalidade, uma nova visão de mundo, fundamentada no conhecimento e servindo como instrumento eficaz para uma ação consciente". Azevedo vai defender, dessa forma, uma nova mentalidade no campo educacional, capaz de transformar a cultura e, por conseguinte, a consciência dos brasileiros.

Dessa forma, no projeto de educação de Azevedo se faz presente, conforme Penna (2010, p. 18),

[...] a necessidade de uma nova mentalidade, capaz de compreender as funções de uma sociedade moderna, refazendo a ordem de prioridades educacionais, de acordo com essas novas funções, as relações entre 
educação e política, a importância do inquérito de 1926, a experiência administrativa no Distrito Federal, a concepção da escola do trabalho, a escola-comunidade.

Será em torno desse projeto e de sua materialização que Fernando de Azevedo se organizará enquanto educador e sociólogo, entre 1930 e 1960, muito embora ele, segundo Penna (2010, p. 16), “[...] nunca conseguiu concretizar de fato seus planos para uma 'revolução copérnica' na esfera da educação". Dessa forma, segundo Durmeval Trigueiro Mendes, prefaciador do livro de Penna (1987, p. xiii), será o pensamento de Fernando de Azevedo, com sua posição "[...] abrangente, às vezes pioneira, afirmativa e ambígua, otimista e amarga entre a escola demiúrgica e a sociedade constrangente" o objeto privilegiado pelo trabalho da referida autora.

O terceiro texto a ser considerado é o de Olinda Evangelista e Silvia Leni Auras de Lima, denominado Fernando de Azevedo: sociólogo e educador. Evangelista, graduada em filosofia, vem trabalhando com Fernando de Azevedo desde 1997, quando defendeu a tese de doutorado intitulada A Formação do professor em nível superior - $O$ Instituto de Educação da Universidade de São Paulo (1934-1938), no Programa de Pós-Graduação em Educação da Pontifícia Universidade Católica de São Paulo, área de concentração História, Política, Sociedade. Dessa forma, sua tese abrange o período em que Fernando de Azevedo foi diretor do Instituto de Educação ${ }^{8}$. Lima é professora de sociologia do Colégio de Aplicação da Universidade Federal de Santa Catarina (UFSC).

No texto em análise, são apresentados dados biográficos de Fernando de Azevedo, bem como suas propostas para o estudo sociológico (Fernando de Azevedo - um estudioso da sociedade, texto de Silvia Leni Auras de Lima) e para o campo educacional (Fernando de Azevedo - o educador, texto de Olinda Evangelista). No caso da sociologia, enfatiza-se sua importância para a análise dos processos educacionais, bem como para a construção das propostas defendidas pelo autor. Segundo Lima,

Mediante o aprofundamento teórico em Sociologia, Fernando de Azevedo interessou-se pela questão educacional adquirindo uma visão "renovada", contrária à educação autoritária e conservadora que recebera de seus mestres. [...] $\mathrm{Na}$ verdade, Azevedo voltava-se para a ordem e a solidariedade na sociedade industrial. [...] A educação seria a agenciadora de uma nova consciência moral, ao mesmo tempo que propiciaria ao indivíduo desenvolver suas potencialidades para o trabalho ou para a atividade intelectual, dependendo de suas aptidões naturais, tornando-o cada vez mais capacitado para viver em sociedade. (EVANGELISTA; LIMA, 2008, p. 24).

Em relação à questão educacional, sobressaem as análises e proposições de Azevedo para a formação de professores, com destaque para a defesa dos cursos superiores voltados para a formação docente, centrada particularmente na experiência do educador na direção do Instituto de Educação da USP. Com esse propósito, lembra a autora que Fernando de Azevedo foi "[...] parte de uma geração de intelectuais 'interventores', que diziam o que o mundo deveria ser, o que a sociedade deveria ser, o que a cultura deveria ser. Mais do que fazer a educação, Azevedo queria fazer o mundo. (EVANGELISTA; LIMA, 2008, p. 67. Os grifos são nossos.).

Ora, nesse projeto a educação ocupava lugar central, pois caberia a ela produzir uma "nova" cultura brasileira. Para tal tarefa fazia-se necessária e imprescindível a 
formação de professores com o devido preparo técnico-profissional, o que exigia o concurso do ensino superior. Essa demanda deu lastro para a defesa da criação do Instituto Superior de Educação, como parte da recém-criada Universidade de São Paulo (IEUSP). Assinala Evangelista:

Tratava-se de demonstrar, pelo exemplo dado, aos intelectuais a inexorabilidade da ciência e a pertinência - técnica, científica e moral das teorias que a IEUSP advogava e produzia. Atuando no ensino, na pesquisa e na extensão, a tríplice missão da "idéia universitária", o projeto de Azevedo acentuava a produção da ciência argumentando para ser-se professor havia que se produzir ciência. A trindade das ciências fontes da educação - Psicologia, Biologia e Sociologia - constituíam o campo sobre o qual se construiria uma ciência do homem. (EVANGELISTA; LIMA, 2008, p. 90).

Dessa forma, seria possível criar-se aquele que interveria no sentido da formação moral exigida tanto para a intervenção das elites condutoras, como das massas. Isso colocou para a direção do IEUSP inúmeras demandas, que iam desde "[...] edifício que sediaria tal programa [...] [até a] criação de espaços novos - salas-ambientes, bibliotecas, gabinetes, serviços, auditório, laboratórios, pátios, campos de jogos, expressão das tendências pedagógicas renovadoras" (EVANGELISTA; LIMA, 2008, p. 91).

Tal proposta teve existência curta, pois em junho de 1938 o IEUSP foi extinto, já no período do Estado Novo, em grande medida devido à forte resistência que o projeto sofreu por parte dos educadores católicos. Em suma, ao debruçarem-se de forma detalhada sobre o projeto de Fernando de Azevedo para a formação de professores primários e secundários, não somente no âmbito do pensamento azevediano mas também explorando a forma/conteúdo como esse projeto se materializou na criação do IEUSP, as autoras fornecem elementos importantes para se pensar a questão da organização do trabalho didático na proposta de Fernando de Azevedo.

Finalizando a apresentação de alguns educadores que se debruçaram sobre a obra de Fernando de Azevedo, citar-se-á a coletânea organizada por Maria Elisabeth Blanck Miguel $^{9}$; Diana Gonçalves Vidal ${ }^{10}$ e José Carlos Souza Araújo ${ }^{11}$, intitulada Reformas Educacionais: as manifestações da Escola Nova no Brasil (1920 a 1946), publicada em 2011.

No caso do livro Reformas Educacionais: as manifestações da Escola Nova no Brasil (1920 a 1946), conforme os organizadores, seu objetivo é oferecer aos alunos e pesquisadores da educação o acesso a análises que problematizem as várias maneiras como a Escola Nova foi compreendida por políticos e educadores, e os diversos modos como seus princípios foram traduzidos em legislações e práticas escolares (MIGUEL; VIDAL; ARAÚJO, 2011). O livro contém 23 capítulos, que abarcam reflexões sobre as reformas ocorridas em vários estados e no Distrito Federal (Sampaio Dória, 1920, São Paulo; Reforma da Instrução Pública, 1922-1923, Ceará; Reforma Carneiro Leão, 1922-1926, Distrito Federal; Reforma da Instrução Pública,1924-1928, Bahia; Reforma Francisco Campos, 1927-1930, Minas Gerais, entre outras); e sobre as manifestações da Escola Nova no Espírito Santo, Mato Grosso; Paraná; Pernambuco; Sergipe, entre outros.

Dentre os vinte e três capítulos, três se referem às ações realizadas por Fernando de Azevedo, além do anexo que traz o Manifesto dos Pioneiros da Educação Nova ${ }^{12}$, para cuja elaboração Azevedo foi decisivo. 
Assim, no capítulo O Inquérito sobre a Instrução Pública (1926) e as disputas em torno da educação em São Paulo, Vidal mostra o cenário de comemorações vivido nos anos de 1920, devido aos centenários, primeiro da Independência (1922) e depois da organização do ensino primário (1927), que compunham o contexto daquele período no qual Fernando de Azevedo organizou o Inquérito sobre a Instrução Pública em São Paulo. A autora revela as condições em que ele foi produzido e seus principais temas, concluindo que

[...] de certa forma, o inquérito cumpriu o desígnio da era dos centenários (balanços e prospecção). Ao avaliar o estado da Instrução paulista, produziu um repertório de propostas utilizadas por Azevedo para a intervenção na educação carioca. Retomadas em parte, posteriormente, serviram para organizar mudanças no ensino paulista, quando o educador assumiu o cargo de diretor geral de instrução no estado de São Paulo e elaborou o Código de 1933. (VIDAL, 2011, p. 118).

O outro capítulo também relativo a Azevedo, intitulado A Reforma Fernando de Azevedo e as Colmeias Laboriosas no Distrito Federal de 1927 a 1930, foi escrito por Sônia de Oliveira Camara Rangel [Sônia Camara] ${ }^{13}$ e trata da Reforma promovida no Distrito Federal em 1927. A autora mostra Azevedo como o desbravador da educação que, coordenando a Reforma, revelou seus princípios de "escola para todos". Conforme a autora, a cidade do Rio de Janeiro vivenciou, em meados do século XIX, “[...] um processo de intervenção embalado por ações higiênicas e educativas que pretenderam ordenar e regularizar o espaço urbano, reordenando-o a partir da lógica burguesa europeia" (CÂMARA, 2011, p. 187). Nesse contexto,

[...] por meio da educação, pretendia-se instituir práticas ordinárias ao viver da população [...]. Por meio da criança, esperavam transmitir valores, mas também produzir novos saberes que interferissem no meio social do qual provinha. [...] Para Fernando de Azevedo, a modernização educacional seria feita tanto pelos programas de ensino a serem ministrados, como pela remodelação dos prédios escolares e por novas práticas educativas realizadas no cotidiano da escola, cabendo ao estado a tarefa de diluir as diferenças sociais, econômicas e culturais na cidade. (CÂMARA, 2011, p. 187).

Fernando de Azevedo e a Reconstrução do Sistema Educacional do Estado de São Paulo em 1933: sentidos e alcances de um projeto de reforma é o terceiro dos três capítulos considerados. Nele a autora, Rosa Fátima de Souza ${ }^{14}$, examina a atuação de Azevedo no cargo de Diretor do Departamento de Educação do estado de São Paulo e analisa as possibilidades de interpretação do alcance da reforma por ele implementada. Para Souza (2011, p. 358), a historiografia por ela consultada tem razão ao afirmar que a atuação de Fernando de Azevedo em São Paulo é melhor compreendida quando relacionada ao conjunto das políticas educacionais implementadas no período. Isto porque é possível verificar "[...] a existência de um projeto comum de reforma da educação e de modernização do ensino público paulista compartilhado especialmente por intelectuais como Fernando de Azevedo, Lourenço Filho e Almeida Júnior" (SOUZA, 2011, p. 358).

Concluindo, o foco dos trabalhos apresentados nessa última coletânea - Reformas Educacionais: as manifestações da Escola Nova no Brasil (1920 a 1946) - também se 
detém prioritariamente nas propostas e nas realizações de Fernando de Azevedo enquanto reformador, preocupado com a formulação e execução da educação nova no Brasil.

Em relação ao campo da sociologia, que conta com um número menor de pesquisas sobre Fernando de Azevedo, conforme afirmado anteriormente, o primeiro trabalho a ser destacado é a dissertação de mestrado de Simone Meucci ${ }^{15}$, intitulada A institucionalização da sociologia no Brasil: os primeiros manuais e cursos, defendida no ano 2000, no Programa de Pós-Graduação em Sociologia da UNICAMP (MEUCCI, 2000). O objeto dessa dissertação são os textos escolares produzidos para a disciplina sociologia nos cursos de direito - produção esta que se adensou sobretudo nas primeiras décadas do século XX e, principalmente, os compêndios produzidos para o ensino secundário, que avultaram entre as décadas de 1930 a 1940, quando a disciplina se tornou obrigatória nesse grau de ensino $^{16}$. Nessa direção, Meucci esclarece que "Os primeiros veículos dedicados à difusão ampla da disciplina sociológica nos ajudam, em síntese, a compreender como se constituiu entre nós, num só tempo, a sociologia, seu objeto e seus sujeitos" (MEUCCI, 2010, p. 6).

Foi nesse universo, formado por cerca de duas dezenas de textos escolares, produzidos principalmente entre 1931 e 1945, que se encontram os compêndios examinados pela autora. É interessante destacar-se algumas observações sobre aspectos que caracterizam esses textos escolares e seus autores:

a) "A maioria dos manuais era, pois, resultado da organização dos conteúdos dos cursos que os autores ministravam" (MEUCCI, 2010, p. 18). Como exemplos, são destacados os textos de Alceu Amoroso Lima (Iniciação à Sociologia, que circulara em páginas datilografadas entre os alunos do Instituto Superior de Estudos Católicos); Carneiro Leão (Fundamentos de sociologia) e Gilberto Freyre (Sociologia: Introdução aos seus princípios, resultante de aulas ministradas na Universidade do Distrito Federal).

b) "[...] a maioria de nossos autores [eram] bacharéis em direito que se envolveram no debate sobre a educação e atuaram no magistério da sociologia. [...] Estamos diante de um fenômeno de passagem dos nossos bacharéis para a área de educação e, desta para a sociologia" (MEUCCI, 2000, p. 19). Essa passagem, segundo a autora, foi motivada principalmente pela preocupação com a formação de professores, ou seja, demonstra o estreito compromisso dos autores com a questão educacional ${ }^{17}$.

c) Ora, o projeto de estudo e intervenção sobre uma "[...] sociedade [que] passara a ser vista como uma realidade complexa, dinâmica, interessante e da qual somos, a um só tempo, sujeitos e agentes" (MEUCCI, 2000, p. 34) exigia não apenas a formação de um novo tipo de professor, mas também de textos escolares que disponibilizassem o conhecimento sintético necessário tanto a quem ensinava, como a quem aprendia. Assim, lembra a autora que, para Fernando de Azevedo, "o autor de compêndios didáticos de sociologia é um abreviador crítico, cuidadoso na exposição e no julgamento dos temas", que em benefício da exatidão, "[...] abre mão das convicções infundadas, do idealismo teórico e estético" (MEUCCI, 2000, p. 37).

d) Em que pese a expectativa dos autores, os compêndios, "[...] sempre em torno de trezentas páginas, parecem, a princípio, não estabelecer nexo entre o conhecimento sociológico e a realidade social brasileira. Era, pois, frequente, nos textos didáticos, uma lista quase interminável de conceitos, escolas sociológicas, sociologias especiais, autores e métodos de pesquisa" (MEUCCI, 2000, p. 40). Ou seja, apesar da reiterada perspectiva dos autores dos textos escolares, sintetizada na proposta de Carneiro Leão, de livrar os alunos da tirania do compêndio, os mesmos acabam por se estruturar nos mesmos moldes da tradição intelectual que se pretendia evitar. 
e) Simultaneamente, contudo, a proposta de síntese voltada à facilitação do trabalho didático, segundo os princípios da nova pedagogia, também estava presente nesses textos, e "por isso, ao final de cada capitulo, eram sugeridos aos alunos um conjunto de tarefas relacionadas ao aprofundamento dos temas tratados em sala de aula. Estas tarefas compreendiam o preenchimento de questionários, o levantamento de bibliografia complementar para realização de trabalhos escritos, seminários e debates, e sobretudo, o desenvolvimento de trabalhos de campo e inquéritos sociológicos" (MEUCCI, 2000, p. 41). Isso exigia, em última instância, não apenas um professor ativo mas sobretudo conhecedor da matéria envolvida na área sociológica.

Tendo em vista essas características, Meucci passa à análise de textos escolares específicos, dentre eles aqueles produzidos por Fernando de Azevedo. Para tal, dedica uma parte de sua dissertação ao autor (Durkheim como emblema: a sociologia como o estudo dos fatos sociais). Recorda que Princípios de Sociologia, editado pela primeira vez em 1935, foi um compêndio produzido para os cursos de sociologia da USP, mas que também foi utilizado nas escolas normais brasileiras. Da mesma forma, Sociologia Educacional, publicado em 1940, também se destinava à formação dos alunos dos cursos de ciências sociais, mas ganhou espaço igualmente no ensino normal.

Meucci ainda acrescenta que um dos principais esforços de Fernando de Azevedo era,

“[...] sempre com o auxílio de Durkheim, definir a educação como um objeto de investigação sociológica. Quis capturá-la a fim de incorporá-la ao campo [de] estudos sociológicos. Sociologia Educacional representa, pois, mais um dos passos de Azevedo na luta pela constituição do novo caminho para a sociologia. Estivera, como podemos notar, sempre bem acompanhado por Durkheim. (MEUCCI, 2000, p. 81).

Concluindo essa exposição, relembre-se que Meucci (2000) afirma ainda que, para Azevedo, a filiação ao positivismo por meio de Émile Durkheim, era a garantia de conquistar, para a sociologia no Brasil, o status de ciência positiva, um dos objetivos que perseguiu em toda a sua trajetória intelectual.

O segundo trabalho a ser analisado é a dissertação de mestrado de Flávio Marcos Silva Sarandy ${ }^{18}$, denominada $A$ sociologia volta à escola: um estudo dos manuais de sociologia para o ensino médio no Brasil, defendida junto do Programa de Pós-Graduação em Sociologia e Antropologia da UFRJ, em 2004. Tendo como objeto quatro manuais didáticos de sociologia utilizados no ensino médio, Sarandy declara que o seu objetivo é analisar " [...] o ensino de sociologia no ensino médio a partir das propostas dos próprios manuais da disciplina e da produção acadêmica sobre o assunto" (SARANDY, 2004, p. 14).

Nessa direção, Sarandy justifica sua opção pela análise de manuais didáticos lembrando que, apesar do pouco valor social dos mesmos, suas investigações mostram que

[...] os livros didáticos - seja em que suporte os consideremos - têm sido bem mais que mediadores entre alunos e saberes e práticas institucionalizadas, ou mesmo mediadores entre alunos e professores no contexto de sala de aula, já que também têm se revelado como a principal fonte de formação do professor [...]. Daí a necessidade de se conhecer melhor esse objeto "variável" e de difícil apreensão que constitui o principal instrumento de escolarização e letramento de grande parte da 
sociedade brasileira, além de principal referência para um expressivo número de docentes. (SARANDY, 2004, p. 21-22. Grifos do autor.).

Dessa forma, o autor levanta uma questão significativa: que os manuais didáticos utilizados por professores da área de sociologia, “[...] sejam, antes de tudo, manuais de formação do próprio professor da disciplina, lhe fornecendo a orientação a seguir para a construção de um programa de curso e, não raro, os conteúdos a serem ministrados" (SARANDY, 2004, p. 24). Ora, segundo se depreende das análises de Meucci (2000), essa perspectiva "formadora dos textos escolares", incluindo-se aí os compêndios de sociologia, já estava presente no horizonte dos educadores como Fernando de Azevedo, quando declara que "[...] não se improvisa um pesquisador ou um experimentador. Nem em física, nem em química, nem em sociologia" (AZEVEDO, 1939 apud MEUCCI, 2000, p. 79. Grifos do autor.). Dada a preocupação de Fernando de Azevedo com o papel da formação de sociólogos e professores, pode-se daí depreender que também não se improvisa um professor e que, portanto, os textos escolares têm um papel fundamental nessa direção.

Fechando a primeira parte deste artigo, apresenta-se a tese de doutorado de Alessandra Santos Nascimento ${ }^{19}$, intitulada Fernando de Azevedo: dilemas na institucionalização da sociologia no Brasil, defendida junto ao Programa de PósGraduação em Ciências Sociais no campus da UNESP/Araraquara. Tendo como objeto o processo de institucionalização da sociologia no Brasil e, no interior desse processo, os dilemas e contribuições de Fernando de Azevedo, seu objetivo principal era, segundo a autora "[...] construir uma versão sobre uma fase da história da Sociologia e, neste caminho, esclarecer algo que se encontrava apenas sugerido e, na maioria das vezes, subestimado: a contribuição de Fernando de Azevedo para a institucionalização" (NASCIMENTO, 2011, p. 8) do ensino e da pesquisa sociológica no Brasil.

Nascimento parte de um pressuposto já defendido, entre outros, por Meucci (2000) de que, no Brasil, a institucionalização disciplinar da sociologia realizou-se com o concurso da educação. Assim no Brasil, diferentemente de outros países latino-americanos, a sociologia ganhou foro institucional por meio da educação, vista a sociologia como instrumento para analisar e planejar as reformas educacionais desejadas. Nesse sentido, gerou a produção de um conjunto de textos escolares que, voltados para a divulgação do conhecimento sociológico, contribuíram para a divulgação e delimitação de um campo institucional para a disciplina; como também fortaleceu a percepção da importância da análise sociológica para o entendimento e enfrentamento dos problemas sociais no Brasil, entre eles o educacional. Tal fato concorreu favoravelmente para a presença de quadros formados em ciências sociais nos principais órgãos de gestão e pesquisa educacionais, como foi o caso do INEP (criado em 1937) e do Centro Brasileiro de Pesquisas Educacionais (CBPE) e suas regionais (que funcionaram a partir de 1955), espalhadas pelo país. Em especial o CBPE e suas unidades nos estados não só acolheram profissionais da área de ciências sociais, como financiaram projetos de pesquisa, dentro e fora da instituição, para a pesquisa social em torno da questão educacional (FERREIRA, 2008).

Em particular a partir dos anos 1950, segundo Nascimento (2011, p. 110), pode-se afirmar que dois projetos, o que defendia a necessidade "de modernização nacional, com ênfase na reforma da educação - defendido por Anísio Teixeira, Fernando de Azevedo e pelo grupo de intelectuais a eles ligado - e, de outro, o de institucionalização das Ciências Sociais e de afirmação da atividade científica no país" se cruzaram e relacionaram. Assim, a obra e a trajetória intelectual de Fernando de Azevedo caminhariam nesse sentido, como "Vocações que se entrecruzaram e tiveram lugares igualmente importantes em termos 
científicos, na trajetória e obra deste autor, mas estrategicamente distintos, em termos políticos (EVANGELISTA; LIMA, 2008; BOMENY, 1999 apud NASCIMENTO, 2011, p. 143)".

Nesse projeto educacional e sociológico de Fernando de Azevedo, ganhou importância especial o papel do professor, visto como um elemento fundamental na difusão e consolidação, entre as massas e os dirigentes, da necessidade da nova educação, bem como das formas de torná-la presente no contexto nacional. Ora, Nascimento (2011) chama a atenção para um aspecto importante quando enfatiza que, para Azevedo, "[...] o professor só poderia ser um intelectual se produzisse ciência. Para se produzir ciência fazia-se indispensável saber o que ensinar aos alunos e como ensinar. [...] As coleções científicas sob sua direção estabeleceram entre seus objetivos 'ensinar a ensinar' [...]”. Não por acaso, o compêndio Princípios de Sociologia foi denominado "manual científico", pelo autor (BRITO, 2010). O detalhamento desse aspecto, ou seja, o que seria para Fernando de Azevedo "ensinar a ensinar", não foi objeto de reflexão da autora, visto que fugiria ao escopo sugerido para seu trabalho.

Indo em outra direção, seu interesse era compreender as concepções, valores, atitudes, interesses, sentimentos, etc, que, estando presentes no ambiente social e político forjado entre 1930 e 1960, exprimiram "[...] as disputas entre indivíduos e entre grupos pela legitimação de seus diagnósticos e prognósticos sobre o país" (NASCIMENTO, p. 24). Foi nesse campo que, enfatiza Nascimento (2011), se movimentou Fernando de Azevedo, figura ímpar para se compreender tanto o panorama educacional, como o desenvolvimento do ensino e da pesquisa em ciências sociais no Brasil.

\section{Uma nova leitura sobre a produção de Fernando de Azevedo}

Conforme anunciado na introdução deste artigo, inicia-se agora uma discussão em torno de outra proposta de leitura em torno da obra de Fernando de Azevedo. É consenso, entre os pesquisadores referidos, a importância de Azevedo para se entender as proposições em torno das reformas educacionais ocorridas no Brasil entre os anos $1930 \mathrm{e}$ 1960 - e isso não apenas pela sua participação na escrita e difusão do Manifesto dos Pioneiros da Educação Nova mas também pela materialização desse projeto quando de sua passagem pela gestão educacional, seja no estado de São Paulo ou no Distrito Federal, seja na Universidade de São Paulo ou no Centro Regional de Pesquisas Educacionais, do mesmo estado.

Além disso, todos os autores reconhecem a importância de Fernando de Azevedo para o processo de institucionalização da sociologia no país, seja pelos seus esforços em produzir conhecimento sociológico, seja pela constante divulgação desse conhecimento ou pela insistência de sua inserção como parte da formação do "homem médio", no ensino secundário, ou do professor, no ensino normal. O que deveria ser coroado, certamente, pela formação especializada de um novo profissional, devida à expansão e consolidação da área de ciências sociais no ensino universitário.

Com esse intuito, os vários autores referidos anteriormente vasculharam detidamente a produção de Fernando de Azevedo, distinguindo seus matizes teóricometodológicos, as condições em que se deu sua produção, seus principais interlocutores e os produtos advindos desses esforços - seus textos - fossem eles compêndios dedicados ao ensino de sociologia, monografias sociológicas, ensaios e trabalhos avulsos, fruto de suas inúmeras iniciativas nos campos educacional e sociológico. 
Frente a esses preliminares, ao que se remete a proposta de estudo que ora se propõe? Partindo das mesmas fontes primárias, procurar-se-á na produção azevediana os elementos que permitam analisar as proposições do autor em torno da organização do trabalho didático.

Nesse sentido, o primeiro elemento a ser definido é a própria categoria que guiará a análise. Em outros termos, o que significa organização do trabalho didático? A base para a resposta a essa indagação está nos textos de Alves $(2001 ; 2005)^{20}$, principalmente o que surgiu como resultado de sua pesquisa de pós-doutorado, intitulado A produção material da escola pública contemporânea, produzido em 1998 e publicado inicialmente em 2001; e Trabalho didático: formas históricas, publicado em 2005. Partindo do pressuposto de que o homem existe a partir do fato de que produz as suas próprias condições de existência, a atividade humana mais fundamental para que se produza o próprio homem se torna a atividade mais importante para o próprio ser homem. Essa atividade, iminentemente humana, que nos permite criar as condições de nossa própria existência, é o trabalho. Segundo Marx,

O trabalho é, antes de tudo, um processo entre o homem e a natureza, processo este em que o homem, por sua própria ação, medeia, regula e controla se metabolismo com a natureza. [...] A fim de se apropriar da matéria natural de uma forma útil para sua própria vida, ele põe em movimento as forças naturais pertencentes a sua corporeidade: seus brações e pernas, cabeça e mãos. Agindo sobre a natureza externa e modificando-a por meio desse movimento, ele modifica, ao mesmo tempo, sua própria natureza. (MARX, 2013, p. 255).

Assim, quando se trata da educação, como parte das condições necessárias à existência humana, não se pode desconsiderar que também é necessário ao homem produzir as condições materiais e espirituais necessárias a um dado projeto educacional. Em torno desse aspecto, pode-se inferir que trabalho didático, como categoria subsidiária, relaciona-se à categoria mais fundamental, anteriormente referida, que é o trabalho. Dessa forma, chega-se à formulação trabalho didático. Por que trabalho didático? Nas palavras de Alves, em termos históricos, o termo didática ganhou um significado especial a partir da proposta de João Amós Comênio (1572-1690) quando, em plena transição da sociedade feudal para a sociedade capitalista, lança o desafio da construção de uma nova forma de "ensinar tudo a todos", projeto posto para a educação na nova sociedade que se consolidava. Assim, enfatiza que se reconhece Comênio,

[...] em especial, como a fonte legitimadora da expressão 'trabalho didático'. Na obra comeniana, foi corrente a utilização do termo 'didática' significando 'proposta de educação para a sociedade' [...]. De acordo com esse entendimento, chamou 'Didática Magna' à proposta geral por ele concebida para responder à demanda social que reclamava o oferecimento de educação escolar para todos. (ALVES, 2012, p. 171).

A partir da proposta comeniana, que viu na didática um projeto educacional para o conjunto da sociedade, Alves chama a atenção para a necessidade de se precisar uma categoria que lhe é correlata, a organização do trabalho didático. Para tal, efetua incursões pelos momentos históricos anteriores ao capitalismo, uma vez que outros projetos educacionais, condizentes a outras organizações sociais histórica e socialmente constituídas, devem ser referidas na história humana, desde as "comunidades primitivas", 
passando pela antiguidade e feudalismo, se nos atermos somente ao ocidente. Ora, em todos esses modos de produzir a vida humana esteve presente e se fez necessário o trabalho didático $^{21}$, desenvolvido a partir de uma dada proposta social e historicamente constituída. Por isso é possível vislumbrar que

No plano mais genérico e abstrato, qualquer forma histórica de 'organização do trabalho didático' envolve, sistematicamente, três aspectos:

a) ela é, sempre, uma 'relação educativa' que coloca, frente a frente, uma 'forma histórica de educador', de um lado, e uma 'forma histórica de educando(s)', de outro;

b) realiza-se com a 'mediação' de recursos didáticos, envolvendo os procedimentos técnico-pedagógicos do educador, as tecnologias educacionais pertinentes e os conteúdos programados para servir ao processo de transmissão do conhecimento;

c) e implica um 'espaço físico' com características peculiares, onde ocorre. (ALVES, 2005, p. 10-11).

Pensar uma nova didática, dessa forma, implicaria em projetar e simultaneamente materializar essa projeção, proposta que foi melhor apresentada, no âmbito da sociedade capitalista, pela obra Didática Magna, de Comênio (2006). Partindo dos três elementos constituintes da organização do trabalho didático, Alves esmiuçou a proposta comeniana, visando analisar como esse educador projetou o trabalho didático no capitalismo.

Em termos de relação educativa, a necessidade de "ensinar tudo a todos" torna imperativa a implantação do ensino coletivo, visto que o ensino preceptorial se dava de forma individualizada e não poderia, portanto, atingir o conjunto de educandos. Para isso, era também necessário o surgimento de um novo educador, capaz de trabalhar com coletivos de alunos, tendo em vista atingir o "aluno médio": surgiu aí, de fato, a figura do professor, em substituição ao antigo preceptor.

Além disso, para que fosse possível se trabalhar com o "aluno médio", era preciso que esse coletivo de educandos possuísse características, em termos de desenvolvimento cognitivo e maturidade que os aproximasse, tornando possível ao professor o trabalho simultâneo com esse conjunto de alunos. Nesse sentido, Comênio estrutura seu projeto didático a partir da formação de classes, conjunto de alunos agrupados por idade, logo, com condições intelectuais afins. As classes, por sua vez, conformariam uma organização seriada de estudos, partindo das séries menos avançadas (crianças menores) para as séries mais avançadas (adolescentes e jovens). Cada série, ou cada disciplina em uma determinada série estaria sob a responsabilidade de um professor: para Comênio, dado que se dedicaria exclusivamente a essa tarefa, o professor se tornaria trabalhador especializado na "arte de ensinar".

Nessa direção, Alves $(2001 ; 2005)$ chama a atenção para dois aspectos importantes em relação a proposta comeniana: por um lado, o que Comênio visualiza como mais avançado no século XVII, e vai servir de parâmetro para o seu projeto de organização escolar, era exatamente a manufatura. Nesta última, o avanço na produção de mercadorias se dera, entre outros fatores, pela extensão da divisão do trabalho, o que permitiu especializar o trabalhador em uma só tarefa, visando a sua performance máxima. Ou seja, a divisão do trabalho na manufatura permitiu o surgimento do trabalhador parcial, que no caso do trabalho didático, era representado pelo professor-especialista, por um lado. Por outro, a combinação da classe (ensino coletivo e graduado), sob a direção de um único 
professor, permitiria uma rápida expansão da escolarização, em um momento histórico onde existia uma pequena quantidade de professores, aptos a ensinar nas novas condições propostas.

Apesar disso, no entanto, afirma Comênio que essa engrenagem só seria eficaz se fosse possível, tal qual acontecia na manufatura, que qualquer um pudesse exercer a tarefa de ensinar, sendo possível dessa forma produzir, de forma segura e barata, as condições materiais necessárias à expansão escolar. Nesse sentido,

[...] finalmente, serão habéis para ensinar, mesmo aqueles a quem a natureza não dotou de muita habilidade para ensinar, pois a missão de cada um não é tanto tirar da própria mente o que deve ensinar, como sobretudo comunicar e infundir na juventude uma erudição já preparada e com instrumentos já preparados, colocados nas suas mãos. [...] [Assim] porque é que não há-de o professor ensinar na escola todas as coisas, se tudo aquilo que deverá ensinar e, bem assim, os modos como ohá-de ensinar, o tem escrito como em partituras? [...]

Uma só coisa é de extraordinária importância, pois, se ela falta, pode tornar-se inútil toda a máquina, ou, se está presente, pode pô-la em movimento: uma provisão suficiente de livros pan-metódicos. (COMÉNIUS, 2006, p. 457; 469).

Surgiu assim a proposta do manual didático, que seria o principal instrumento de trabalho do professor, garantia de que o trabalho didático se realizaria a contento. Ali estariam condensadas, de fato, todo o instrumental necessário ao desenvolvimento das atividades previstas na escolarização. Segundo Alves,

O manual didático surgiu com a pretensão de consubstanciar uma síntese dos conhecimentos humanos sob uma forma mais adequada ao desenvolvimento e à assimilação da criança e do jovem. Especializou-se, também, em função dos níveis de escolarização e das áreas de conhecimento, multiplicando-se da mesma forma que os instrumentos de trabalho, dentro da oficina, que, por força da divisão do trabalho, ganharam as configurações mais adequadas às operações que realizavam. Desde então, o manual didático passou a servir em tempo integral ao aluno e ao professor. (ALVES, 2001, p. 86).

Além disso, o surgimento do manual didático permitiu um certo grau de objetivação e simplificação do trabalho didático. Objetivação, à medida em que se tornou o elemento central na relação educativa, dirigindo o desempenho do professor. Como sugerem os trabalhos de Meucci (2000), para os textos escolares de sociologia dos anos 1930 e 1940, e principalmente Sarandy (2007) para os textos escolares de sociologia do século XXI, tal era a intenção dos autores dessas obras: permitir, por meio delas, a "formação do professor", seja dirigindo a organização de conteúdo, seja sugerindo a forma mais adequada de desenvolvê-los.

Quanto a simplificação, Alves (2001; 2005) recorda que, antes de Comênio, o educador recorria a outros instrumentos de trabalho, tais como o texto clássico; ou as antologias, reunindo excertos de obras clássicas, algumas acrescidas de comentários de seus organizadores. Trabalhar com esses instrumentos de trabalho exigia do educador o conhecimento das fontes clássicas, nas quais estavam lastreadas as antologias ou os textos clássicos integrais. Como afirmado anteriormente, o manual didático, de outra feita, vem 
substituir esses antigos instrumentos de trabalho, de forma a permitir que qualquer professor, por meio de sua utilização, fosse capaz de ensinar. Acrescente-se a isso que a proposta comeniana incluía o pressuposto de "[...] é essencial [...] não dar ao aluno nenhuns outros livros, além dos da sua classe" (COMÉNIO, 2006, p. 430).

Vale lembrar aqui que existem diferenças, em relação à objetivação e simplificação do trabalho didático e o papel do instrumento de trabalho, nesse processo histórico que vai do século XVII ao século XXI. Nessa direção, enfatiza Alves que a organização do trabalho didático prevista por Comênio, determinada para sua realização por condições sociais e históricas que somente se consolidaram a partir de meados do século XIX, se materializou de forma mais clara a partir do final do oitocentos, em países como França, Alemanha e Estados Unidos; e em meados do século XX, em países como o Brasil ${ }^{22}$.

Com base nisso, no caso do Brasil, deve-se afirmar que os textos escolares dos anos 1930-1940 apresentam especificidades em relação aos do século XXI, mesmo porque se tratam de dois momentos históricos distintos da trajetória histórica de produção dessas obras.

A título de exemplo, basta lembrar a descrição de Meucci (2000) sobre os textos escolanovistas, alentados compêndios com 300 páginas em média, o que leva a autora a enfatizar o caráter enciclopédico dos mesmos, questão inclusive que contradizia a crítica realizada pela Escola Nova à "pedagogia tradicional". Além disso, é importante acrescentar que esses compêndios, como frisam Alves e Centeno (2010) ao analisar os volumosos textos escolares escritos para a disciplina de história - característica dessa modalidade de obra, também ressaltada pelos autores - não eram acompanhados de ilustrações, assim como, em geral, eram dirigidos a diferentes públicos, em especial no século XIX. No caso daqueles que foram pensados especificamente para a escolarização, tanto poderiam ser utilizados no ensino secundário ou normal, como no ensino superior - $\mathrm{o}$ que vai marcar os compêndios produzidos nas primeiras décadas do século XX.

De outra feita, os textos escolares de sociologia produzidos entre o final do século XX e início do século XXI, a exemplo daqueles analisados por Sarandy (2007) e por Brito $(2010)^{23}$, se dirigem apenas ao ensino médio, apresentando de forma sintética o rol de conteúdos priorizados pelo autor. Além disso, Alves (2001) enfatiza que há uma preocupação explícita de seus autores com a utilização do manual didático; por isso, parte desses textos escolares são dedicadas à explicitação dos melhores procedimentos a serem adotados pelo professor para seu uso ${ }^{24}$.

Assim, a proposta de leitura da produção de Fernando de Azevedo que ora se apresenta baseia-se na concepção de trabalho didático e organização do trabalho didático anteriormente expostas, sendo essas as categorias basilares para a investigação. No caso em questão, considera-se essa proposta significativa por se tratar de um autor que não somente escreveu acerca das condições do trabalho didático, mas também foi produtor de textos escolares dedicados ao ensino de sociologia e latim, além de gestor de reformas educacionais que também visavam criar as condições para uma organização do trabalho didático em novas bases.

\section{Considerações finais}

Em relação aos objetivos desse artigo, pode-se dizer que a produção anteriormente examinada apresenta alguns elementos importantes para uma outra leitura da obra de Fernando de Azevedo. O primeiro deles é que os autores analisados geraram um conjunto significativo de inventários sobre a produção de Fernando de Azevedo (PENNA, 1987; 
EVANGELISTA; LIMA, 2008; NASCIMENTO, 2011). Além disso, trabalhos de sistematização como o realizado pelo NIEPHE ${ }^{25}$ (NIEPHE, 2014; VIDAL, 2000) fornecem elementos que permitem a melhor utilização do acervo privado do referido educador, depositado no IEB.

O segundo elemento a destacar é que se encontram nos trabalhos analisados informações que permitem conhecer-se as condições nas quais viveu Fernando de Azevedo, bem como as propostas educacionais e sociológicas que animaram sua produção (EVANGELISTA; LIMA, 2008; MEUCCI, 2000; MIGUEL, VIDAL, ARAUJO, 2011; NASCIMENTO, 2011; PENNA, 1987; PILETTI, 1982; SARANDY, 2007). Nessa perspectiva, os textos desses autores, portanto, compõem algumas das leituras possíveis sobre a obra de Fernando de Azevedo.

Enfatize-se, contudo, que as leituras aqui apresentadas também apontam alguns elementos acerca da visão de Azevedo sobre o trabalho didático e sua organização, tendo em vista a constituição de um novo saber e uma nova prática educacional. Tais elementos, tratados mais de perto em especial por Meucci (2000) e Sarandy (2007), são a utilização dos textos escolares, as diretrizes acerca do trabalho do professor e da formação necessária à realização de tal empreita. Outro desses elementos, presente no trabalho de Evangelista e Lima (2008), diz respeito às condições materiais e aos elementos de mediação necessários à formação de professores "renovados", capazes de desenvolver um trabalho didático em outras bases. Destaque-se que essas foram questões que se destacaram quando as autoras se debruçaram sobre as propostas de Fernando de Azevedo para o IEUSP.

Assim, acredita-se que seja necessário e oportuno, aprofundando-se em especial estas últimas questões e suas correlatas - a relação entre professor e aluno (ensino coletivo), as mediações necessárias à realização do processo educacional (currículos, materiais pedagógicos, além dos textos escolares) e o espaço físico adequado para tal contribuir-se para um conhecimento mais profundo e extenso acerca de Fernando de Azevedo e seu projeto para a educação no Brasil.

\section{Referências}

ALVES, G. L. A produção da escola pública contemporânea. Campinas: Autores Associados, 2001.

História da educação: a produção teórica sobre o trabalho didático. In: BRITO, S. H. A. de et al. (Orgs.). A organização do trabalho didático na história da educação. Campinas: Autores Associados; HISTEDBR, 2010. p. 41-59.

O trabalho didático na escola moderna: formas históricas. Campinas: Autores Associados, 2005.

Organização do trabalho didático: a questão conceitual. Acta Scientiarum.

Education, Maringá, v. 34, n. 2, p. 169-178, jul./dez. 2012. Disponível em: <http://periodicos.uem.br/ojs/index.php/ActaSciEduc/article/view/17180/pdf >. Acesso em 15 out. 2014.

ALVES, G. L.; CENTENO, C. V. A produção de manuais didáticos de história do Brasil: remontando ao século XIX e início do século XX. Revista Brasileira de Educação, v. 14, n. 42, p. 469-487, set./dez. 2009. 
ARAUJO, J. C. S. Concepções de universidade e de Educação Superior no Inquérito de 1926 de Fernando de Azevedo (1874-1974). Revista Brasileira de História da Educação, v. 17, p. 73-102, 2008.

Direitos Humanos, Educação e o Escolanovismo de Fernando de Azevedo (18941974). In: LOMBARDI, José Claudinei; NASCIMENTO, Maria Isabel; SAVIANI, Dermeval. (Org.). Navegando pela História da Educação Brasileira. Campinas: Grupo de Estudos e Pesquisas "História, Sociedade e Educação no Brasil' (HISTEDBR), 2006. v. 1, p. $1-17$

Entre o universal e o particular: o direito à educação e suas expressões em Fernando de Azevedo (1894-1974). In: MONTEIRO, F. M. de A.; MÜLLER, M. L. R. (Org.). Educação como espaço da cultura. Cuiabá: EdUFMT, 2007. v. 2, p. 95-108.

. O ideário escolanovista n'O Problema Universitário Brasileiro, Inquérito de 1928. In: MIGUEL, M. E. B.; VIDAL, D. G.; ARAUJO, J. C. Reformas Educacionais: as manifestações da Escola Nova no Brasil (1920 a 1946). Campinas: Autores Associados; Uberlândia: EDUFU, 2011b. p. 179-192.

\section{ARQUIVO FERNANDO DE AZEVEDO. Reforma da Instrução Pública no Distrito} Federal (RJ) 1927-1930. São Paulo: IEB/USP, cd-rom, 2000.

BRITO, S. H. A. de B. A produção de manuais didáticos e o ensino de Sociologia na escola média em dois momentos históricos (1935-1989). Revista HISTEDBR On-line, v. 37, p. 58-75, 2010.

O ensino de sociologia e a organização do trabalho didático no Colégio Pedro II (1925-1945). Rev. bras. hist. educ., Campinas-SP, v. 12, n. 3 (30), p. 95-124, set./dez. 2012.

et al. O manual didático como instrumento de trabalho nas escolas secundária e normal (1835-1945). Campo Grande: 2012. Relatório final (Projeto de pesquisa).

CAMARA, S. [Sônia de Oliveira Camara Rangel]. A Reforma Fernando de Azevedo e as Colmeias Laboriosas no Distrito Federal de 1927 a 1930. In: MIGUEL, Maria Elisabeth Blanck; VIDAL, Diana Gonçalves; ARAUJO, José Carlos. Reformas Educacionais: as manifestações da Escola Nova no Brasil (1920 a 1946). Campinas: Autores Associados; Uberlândia: EDUFU, 2011. p. 152-167.

Reinventando a Escola: O Ensino Profissional Feminino na Reforma Fernando de Azevedo de 1927 a 1930. Niterói: 1997. Dissertação (Mestrado em Educação) Universidade Federal Fluminense.

Reinventando a escola: a reforma Fernando de Azevedo no Distrito Federal de 1927 a 1930. Rio de janeiro: Quartet, 2013. 
CARDOSO, M. A. A Organização do Trabalho Didático nas Escolas Isoladas

Paulistas: 1893 a 1932. Campinas: 2013. Tese (Doutorado em Educação) - UNICAMP.

CENTENO, C. V. O manual didático Projeto Araribá na história no município de Campo Grande, MS (2008). Revista HISTEDBR On Line, Campinas, número especial, p. 20-35, maio 2010.

EVANGELISTA, O. A Formação do professor em nível superior: o Instituto de Educação da Universidade de São Paulo (1934-1938). São Paulo: 1997. Tese (Doutorado em Educação) - PUC/SP.

A formação Universitária do Professor: o Instituto de Educação da Universidade de São Paulo (1934-1938). Florianópolis: NUP; Cidade Futura, 2002.

EVANGELISTA, O.; LIMA, S. L. A. de. Fernando de Azevedo: sociólogo e educador. Florianópolis: Edufsc, 2008.

FERREIRA, M. S. Os Centros de Pesquisas Educacionais do INEP e os estudos em ciências sociais sobre a educação no Brasil. Revista Brasileira de Educação, v. 13, n. 38, p. 279-411, maio/ago. 2008.

GIGLIO, Adriano Carneiro. A Sociologia na Escola Secundária: Uma Questão das Ciências Sociais no Brasil - Anos 40 e 50. Rio de Janeiro: 1999. Dissertação (Mestrado em Sociologia) - Instituto Universitário de Pesquisas do Rio de Janeiro.

HOFF, S. A história da organização do trabalho didático: a palavra e a coisa. In: BRITO, Silvia Helena Andrade de et al. (Orgs.). A organização do trabalho didático na história da educação. Campinas: Autores Associados; HISTEDBR, 2010. p. 177-185.

Apresentação. In: RATKE, Wolfgang. Escritos sobre A Nova Arte de Ensinar de Wolfgang Ratke (1571-1635): textos escolhidos. Tradução e notas de Sandino Hoff. Campinas: Autores Associados, 2008.

MARZ, K. O capital: crítica da economia política. São Paulo: Boitempo, 2013. livro 1: o processo de produção do capital.

LANCILLOTTI, S. S. P. Manuais de Psicologia - instrumentos de trabalho utilizados na formação dos professores paulistas (1920-1940). Cadernos de História da Educação, v. 12, n. 1, p. 29-44, jan./jun. 2013.

MEKSENAS, Paulo. Sociologia. 2.ed.rev.aum. São Paulo: Cortez, 1994.

MEUCCI, S. A institucionalização da sociologia no Brasil: os primeiros manuais e cursos. Campinas: 2000. Dissertação (Mestrado em Sociologia) - UNICAMP.

Gilberto Freyre e a sociologia no Brasil: da sistematização à constituição do campo científico. Campinas: 2006. Tese (Doutorado em Sociologia) - UNICAMP. 
Institucionalização da sociologia no Brasil: primeiros manuais e cursos. São Paulo: Hucitec: Fapesp, 2011.

MIGUEL, M. E. B. A Formação do Professor e a Organização Social do Trabalho. Curitiba: Editora UFPR, 1997.

A Pedagogia da Escola Nova no Paraná: início, consolidação e expansão do movimento. São Paulo: 1992. Tese (Doutorado em História e Filosofia da Educação) Pontifícia Universidade Católica de São Paulo.

MIGUEL, M. E. B.; VIDAL, D. G.; ARAUJO, J. C. Reformas Educacionais: as manifestações da Escola Nova no Brasil (1920 a 1946). Campinas: Autores Associados; Uberlândia: EDUFU, 2011.

NASCIMENTO, A. S. Cultura organizacional: cultura brasileira e humanismo na obra de Fernando de Azevedo. Araraquara: 2010. Monografia (Especialização em Governança Pública e Novos Arranjos de Gestão) - UNESP/Araraquara.

Fernando de Azevedo: dilemas na institucionalização da sociologia no Brasil. Araraquara: 2011. Tese (Doutorado em Sociologia) - UNESP.

. Fernando de Azevedo: dilemas na institucionalização da sociologia no Brasil. São Paulo: Cultura Acadêmica, 2012.

NÚCLEO INTERDISCIPLINAR DE ESTUDOS E PESQUISAS EM HISTÓRIA DA EDUCAÇÃO [NIEPHE/USP]. Publicações. São Paulo: 2014. Disponível em:

<http://www.usp.br/niephe/publicacoes/index.asp>. Acesso em 08 out. 2014.

PACHECO FILHO, Clovis. Diálogo de Surdos: As Dificuldades para a Construção da Sociologia e de seu Ensino no Brasil (1850 - 1935). São Paulo: 1994. Dissertação (Mestrado em Educação) - Universidade de São Paulo.

PENNA, M. L. [Maria Luiza de Oliveira Penna Marques Moreira]. Fernando de Azevedo. Recife: Fundação Joaquim Nabuco; Massangana, 2010. (Coleção Educadores). Disponível em: 〈http://www.dominiopublico.gov.br/download/texto/me4698.pdf>. Acesso em 10 out. 2014.

Fernando de Azevedo: educação e mudança social. Brasília: Inep, 1986. (Série grandes educadores, 3 ).

Fernando de Azevedo: educação e transformação. São Paulo: Perspectiva, 1987.

PERUCCHI, Luciane. Saberes sociológicos nas escolas de nível médio sob a ditadura militar: os livros didáticos de OSPB. Florianópolis: 2009. Dissertação (Mestrado em Educação) - Universidade Federal de Santa Catarina.

PILETTI, N. A Reforma Fernando de Azevedo: Distrito Federal, 1927-1930. São Paulo: 1979. Dissertação (Mestrado em Educação) - Universidade de São Paulo. 
A Reforma Fernando de Azevedo: Distrito Federal, 1927-1930. São Paulo: USP, 1982. (Estudos e documentos, 20).

Fernando de Azevedo. In: FÁVERO, Maria de Lourdes de Albuquerque; BRITTO, Jader de Medeiros. (Orgs.). Dicionário de Educadores no Brasil: da colônia aos dias atuais. Rio de Janeiro: UFRJ/MEC-Inep, 1999. p. 182-186.

Fernando de Azevedo. Revista Estudos Avançados, v. 8, n. 22, p. 181-184, 1994. Disponível em: <http://www.scielo.br/scielo.php?pid=S010340141994000300016\&script=sci_arttext>. Acesso em 14 ago. 2014.

Fernando de Azevedo: a educação como desafio. In: Instituto Nacional de Estudos e Pesquisas Educacionais Anísio Teixeira [Inep]. Prêmio grandes educadores brasileiros: monografias premiadas 1986. Brasília: Inep, 1986. p. 25-117. (Grandes educadores, 3).

SARANDY, F. M. S. A sociologia volta à escola: um estudo dos manuais de sociologia para o ensino médio no Brasil. Rio de Janeiro: 2004. Dissertação (Mestrado em Sociologia e Antropologia) - Universidade Federal do Rio de Janeiro.

O debate acerca do ensino de sociologia no secundário, entre as décadas de 1930 e 1950. Ciência e modernidade no pensamento educacional brasileiro. Revista Mediações (UEL), v. 12, p. 67-94, 2007.

SILVA, K. K. D. da. O estado da arte da sociologia no ensino médio: teses, dissertações e artigos de 1990 a 2009. Campo Grande: 2010.

SOARES, Jefferson da Costa. O ensino de sociologia no Colégio Pedro II (1925 - 1941). Rio de Janeiro: 2009. Dissertação (Mestrado em Educação) - Universidade Federal do Rio de Janeiro.

SOUZA, A. A. A. de. Manuais didáticos de ensino de Língua e Literatura na modernidade: gênese e desenvolvimento histórico. Revista HISTEDBR On Line, Campinas, número especial, p. 6-19, maio 2010.

Ensino de língua e literatura no Brasil do século XIX: o Curso Elementar de Literatura Nacional e as postillas de Rethorica e Poetica utilizados no Imperial Colégio de Pedro II. Cadernos de História da Educação, v. 12, n. 1, p. 15-28, jan./jun. 2013.

SOUZA, R. F. de. Fernando de Azevedo e a reconstrução do sistema educacional de São Paulo em 1933: sentidos e alcances de um projeto de reforma. MIGUEL, Maria Elisabeth Blanck; VIDAL, Diana Gonçalves; ARAUJO, José Carlos. Reformas Educacionais: as manifestações da Escola Nova no Brasil (1920 a 1946). Campinas: Autores Associados; Uberlândia: EDUFU, 2011.p. 337-361.

VIDAL, D. G._(Org.). Na batalha da educação: correspondência entre Anísio Teixeira e Fernando de Azevedo (1929-1971). Bragança Paulista: EDUSF, 2000. 
O exercício disciplinado do olhar: livros, leituras e práticas de formação docente no Instituto de Educação do Distrito Federal (1932-1937). São Paulo: 1995. Tese (Doutorado em Educação) - Universidade de São Paulo.

O exercício disciplinado do olhar: livros, leituras e práticas de formação docente no Instituto de Educação do Distrito Federal (1932-1937). Bragança Paulista: EDUSF, 2001.

O Inquérito sobre a Instrução Pública (1926) e as disputas em torno da educação em São Paulo. In: MIGUEL, Maria Elisabeth Blanck; VIDAL, Diana Gonçalves; ARAUJO, José Carlos. Reformas Educacionais: as manifestações da Escola Nova no Brasil (1920 a 1946). Campinas: Autores Associados; Uberlândia: EDUFU, 2011. p. 177196.

\footnotetext{
Notas:

${ }^{1}$ Doutora em Filosofia e História da Educação pela UNICAMP, Professora do Programa de Pós-Graduação em Educação e Curso de Ciências Sociais/UFMS e membro do GT MS do HISTEDBR.

${ }^{2}$ Doutora em Filosofia e História da Educação pela UNICAMP, Professora do Curso de Pedagogia/UFMS e membro do GT MS do HISTEDBR.
}

${ }^{3} \mathrm{O}$ presente artigo é parte do projeto "A organização do trabalho didático na perspectiva de educadores da Escola Nova (1930-1970)", financiado pelo CNPq e coordenado pela Profa. Dra. Carla Villamaina Centeno (UEMS), como parte das atividades do GT MS do HISTEDBR.

${ }^{4}$ Outros autores, além de Alves, têm se debruçado sobre esse objeto, mais particularmente orientados para a discussão das materializações do trabalho didático (CARDOSO, 2013; HOFF, 2008; 2010); ou visando a análise do elemento central do trabalho didático, o principal instrumento que vem sendo utilizado pelo professor em sala de aula, o texto escolar (BRITO, 2010; 2012; ALVES; CENTENO, 2009; 2010; SOUZA, 2010; 2013); LANCILLOTTI, 2013, entre outros).

5 Isso não significa, contudo, que esses textos não devam ser utilizados em interlocuções futuras, principalmente quando se fizer presente a necessidade de se reconstituir os debates sociológicos e educacionais nos quais Fernando de Azevedo esteve envolvido.

${ }^{6}$ Essa produção deu origem a pelo menos dois livros: A Reforma Fernando de Azevedo: Distrito Federal, 1927-1930, publicado pela Faculdade de Educação da USP, em 1982; e Fernando de Azevedo: a educação como desafio, publicado pelo Inep, em 1986. Afora esses, Piletti é o autor de vários artigos e capítulos de livro sobre Fernando de Azevedo. Cf., para maiores informações, o currículo Lattes do autor, disponível em:

<http://buscatextual.cnpq.br/buscatextual/visualizacv.do?id=K4780764H6>.

${ }^{7}$ Como produtos dessa pesquisa, dois livros foram publicados: o primeiro pelo Instituto Nacional de Estudos e Pesquisas Educacionais Anísio Teixeira (Inep), em 1986, quando a autora teve sua monografia agraciada pelo Prêmio Grandes Educadores Brasileiros (PENNA, 1986); o segundo em 1987, quando o texto Fernando de Azevedo: educação e transformação foi publicado pela Editora Perspectiva (PENNA, 1987). Além disso, em 2010, Maria Luiza Penna organizou e apresentou o volume dedicado a Fernando de Azevedo na Coleção Educadores, patrocinada pelo Ministério da Educação (MEC) (PENNA, 2010).

${ }^{8}$ Em 2002, o texto da tese foi publicado: A formação Universitária do Professor: o Instituto de Educação da Universidade de São Paulo (1934-1938) (EVANGELISTA, 2002). Além disso, a autora possui outros artigos em periódicos sobre o tema. Para maiores informações cf. o currículo Lattes da autora:

<http://buscatextual.cnpq.br/buscatextual/visualizacv.do?metodo=apresentar\&id=K4790682H7>. 


\begin{abstract}
${ }^{9}$ Maria Elisabeth Blanck Miguel é pedagoga, professora e pesquisadora da Pontifícia Universidade Católica do Paraná (PUC/Pr). Sua produção relacionada à Escola Nova inclui sua tese de doutorado, defendida na PUC/SP em 1992, e publicada em 1997, intitulada A Pedagogia da Escola Nova no Paraná: início, consolidação e expansão do movimento, entre outros artigos e capítulos de livro sobre o tema. Cf., para maiores informações, o currículo Lattes da pesquisadora:

$<$ http://buscatextual.cnpq.br/buscatextual/visualizacv.do?id=K4790905A5>.

${ }^{10}$ Diana Gonçalves Vidal é historiadora, professora e pesquisadora da Faculdade de Educação da USP, atuando no Núcleo Interdisciplinar de Estudos e Pesquisas em História da Educação (NIEPHE) e no Centro de Memória da Educação da USP (CME/USP). Possui mais de três dezenas de produtos, entre artigos em periódicos, livros e capítulos de livro, em autoria ou coautoria, relacionados às questões pertinentes a intelectuais ou a Escola Nova no Brasil e no exterior. A título de exemplo, aparecem na bibliografia desse artigo alguns de seus trabalhos, entre eles sua tese de doutorado, defendida na USP em 1995 e depois transformada em livro em 2001, intitulada $O$ exercício disciplinado do olhar: livros, leituras e práticas de formação docente no Instituto de Educação do Distrito Federal (1932-1937) (VIDAL, 1995, 2000, 2001, 2011). Para maiores informações, cf. o currículo Lattes da pesquisadora:
\end{abstract}

$<$ http://buscatextual.cnpq.br/buscatextual/visualizacv.do?id=K4786873Y0〉.

${ }^{11}$ José Carlos Souza Araujo é filosófo e historiador, pesquisador em história da educação e desde os anos 1980 vem se dedicando a estudos relacionados aos fundamentos filosóficos e históricos da Educação Nova (ARAUJO, 2006, 2007, 2008, 2011). Além dos textos citados nesse artigo, cf. o restante dessa produção no currículo Lattes do pesquisador: 〈http://buscatextual.cnpq.br/buscatextual/visualizacv.do?id=K4787936D6〉.

${ }^{12}$ Nunca é demais lembrar que A Reconstrução Educacional no Brasil: ao povo e ao governo. Manifesto dos Pioneiros da Educação Nova é o documento que sintetiza os novos ideais de educação, constituindo-se como uma das bases para todo estudo sobre os intelectuais que o assinaram, assim como para a investigação sobre as reformas que foram implementadas no país nas décadas de 1920 a 1940.

${ }^{13}$ Sônia Camara é professora e pesquisadora da Universidade do Estado do Rio de Janeiro (UERJ), sendo que seu contato com a Escola Nova vem desde sua dissertação de mestrado, defendida em 1997 na Universidade Federal Fluminense (UFF), cujo título é Reinventando a Escola: O Ensino Profissional Feminino na Reforma Fernando de Azevedo de 1927 a 1930, posteriormente transformado em livro, no ano de 2013. Além desses, possui outros trabalhos focados no escolanovismo no Brasil, em autoria ou coautoria. Para mais informações, cf. o currículo Lattes da pesquisadora:

<http://buscatextual.cnpq.br/buscatextual/visualizacv.do?id=K4782621J9>.

${ }^{14}$ Rosa Fátima de Souza é pedagoga, professora e pesquisadora da Universidade Estadual Paulista Júlio de Mesquita Filho, Campus de Marília (UNESP/Marília). Tendo parte de sua produção dedicada à história do ensino primário e secundário e história do currículo, possui vários trabalhos que enveredaram pela questão da história da Escola Nova no Brasil, que podem ser conferidos em seu currículo Lattes: <http://buscatextual.cnpq.br/buscatextual/visualizacv.do?id=K4799763H4〉.

${ }^{15}$ Simone Meucci é cientista social, mestre e doutora em sociologia. Desde sua os anos 1990 tem pesquisado a história da sociologia no Brasil, inicialmente pela análise de seus textos escolares e cursos $(A$ institucionalização da sociologia no Brasil: os primeiros manuais e cursos, UNICAMP, 2000, dissertação de mestrado, transformado em livro em 2011) e, posteriormente, tendo como objeto a obra de Gilberto Freyre (Gilberto Freyre e a sociologia no Brasil: da sistematização à constituição do campo científico, UNICAMP, 2006, tese de doutorado). Além disso, possui outros textos em periódicos e artigos de livros sobre a temática (Cf. para outras informações o currículo Lattes da pesquisadora:

<http://buscatextual.cnpq.br/buscatextual/visualizacv.do?id=K47688661U4>.

${ }^{16}$ A disciplina sociologia foi introduzida no ensino secundário pela Reforma João Luiz Alves/Rocha Vaz, por meio do decreto $16.782 \mathrm{~A}$, de 13 de janeiro de 1925 , que em seu artigo $47^{\circ}$ alocava a disciplina no sexto e último ano do ensino secundário. Sofreu nova mudança com a reforma Francisco Campos (decreto n. 19.890, de 18 de abril de 1931, complementado pelo decreto n. 21.241, de 4 de abril de 1932), quando passou a figurar no currículo do segundo ano do ciclo complementar, para candidatos que se dirigiam às três áreas previstas na legislação: a) direito; b) medicina, odontologia e farmácia; c) engenharia e arquitetura. 
Finalmente, com a reforma Capanema, nos anos 1940, permaneceu obrigatória nas escolas normais, podendo “[...] ser acrescentada ao currículo da escola secundária, na condição de disciplina optativa” (BRITO, 2012, p. 112).

17 Complementando as discussões sobre a relação entre ciências sociais e educação, Meucci lembra que segundo Fernando Limongi (1989 apud MEUCCI, 2000), nos primeiros anos de existência da USP, cursos como o de ciências sociais dependeram de normalistas para compor seu quadro discente, visto que a maior parte de seus alunos eram egressos desse ramo do ensino secundário. Desse conjunto saíram não apenas os futuros professores secundários, mas também “[...] as vocações científicas para o desenvolvimento acadêmico das ciências sociais, sobretudo em São Paulo, onde foram dadas condições efetivas para que os educadores pudessem seguir a carreira acadêmica” (MEUCCI, 2000, p. 54).

${ }^{18}$ Flávio Marcos Silva Sarandy é pesquisador e professor da Universidade Federal Fluminense, possuindo graduação em ciências sociais e mestrado em sociologia. Suas pesquisas versam sobre o ensino de ciências sociais na educação básica, sociologia da educação e história da disciplina sociológica, temas que desenvolveu desde sua dissertação de mestrado (SARANDY, 2004, 2007). Também é membro fundador da Associação Brasileira de Ensino de Ciências Sociais (ABECS).

19 Alessandra Santos Nascimento é cientista social (bacharel e licenciada), mestre e doutora em sociologia pela UNESP/campus de Araraquara. Sua experiência com a obra de Fernando de Azevedo vem desde 2010, quando defendeu a monografia da especialização denominada Cultura organizacional: cultura brasileira $e$ humanismo na obra de Fernando de Azevedo, no curso de Especialização em Governança Pública e Novos Arranjos de Gestão, oferecido pela UNESP/Araraquara, que deu origem a seus primeiros trabalhos sobre esse autor (NASCIMENTO, 2010).

${ }^{20}$ Gilberto Luiz Alves é pedagogo, doutor em filosofia e história da educação, sendo atualmente professor e pesquisador da Universidade Anhanguera-UNIDERP, no Programa de Pós-Graduação em Meio Ambiente e Desenvolvimento Regional. Na área da educação, parte de sua produção foi dedicada à analise do trabalho didático na escola moderna (ALVES, 2001; 2005; 2010; 2012)

${ }^{21}$ Importante lembrar que quando se fala de trabalho está se pensando, necessariamente, em uma atividade humana social, intencional e planejada, ou seja, idealizada nos seus propósitos e finalidades, e materializada a partir dessa projeção, não de forma voluntária mas determinadas pelas condições materiais existentes nessa mesma sociedade. (MARX, 2013).

22 Para maiores detalhes sobre essas especificidades, vide Brito et al (2012), além dos próprios textos de Meucci (2000), ao analisar os compêndios dos anos 1930-1940, e Sarandy (2007), ao tratar dos manuais didáticos dos anos 1980 a 2000.

${ }^{23}$ O texto escolar em questão é Sociologia, de Paulo Meksenas (1994), publicado pela primeira vez em 1989, com várias reedições posteriores.

${ }^{24}$ Em outros manuais didáticos, a medida em que eles se tornam mais especializados - dedicados a uma única etapa de escolarização (ano ou conjunto de anos específicos) - há uma tendência que, da mesma forma que os alunos recebem um texto escolar específico para a disciplina e fase da escolarização em que se encontram, o mesmo ocorra com um professor, que receberá um guia do professor dedicado à tarefa de demonstrar as melhores formas de utilização daquele manual didático. Cf. a respeito dessa questão Alves (2001)

25 Destaque-se aqui duas iniciativas do Núcleo Interdisciplinar de Estudos e Pesquisas em História da Educação (NIEPHE), que foram coordenadas pela pesquisadora Diana Gonçalves Vidal, e que são particularmente importantes para o estudo sobre a obra de Fernando de Azevedo: [a primeira, que reúne] “[...]as [125] cartas escritas por Anísio Teixeira e Fernando [de] Azevedo, entre 1929 e 1971, existentes no arquivo Fernando de Azevedo.; [a segunda,] “[...] a organização de um CDROM, [...] [que pretendia] ser um guia do Arquivo Fernando de Azevedo, doado ao Instituto de Estudos Brasileiros-USP [...]. São cartas, artigos de jornal, manuscritos publicados ou inéditos e fotografias, totalizando aproximadamente 16.000 documentos." Disponível em: <http://www.usp.br/niephe/publicacoes/index.asp>.

Recebido: fevereiro-15 Aprovado: abril-15 